Bangladesh J. Plant Taxon. 13(1): 41-47, 2006 (June)

\title{
DESMIDS FROM SOME SELECTED AREAS OF BANGLADESH: 3. GENUS STAURASTRUM MEYEN (2)
}

\author{
A.K.M. Nurul Islam And Nasima AKTer \\ Department of Botany, University of Dhaka, Dhaka-1000, Bangladesh \\ Key words: Desmids, Staurastrum, Bangladesh
}

\begin{abstract}
The paper deals with 13 taxa belonging to Desmid genus Staurastrum Meyen from some selected areas of Bangladesh. Of these, eight taxa are new records for Bangladesh and two taxa are new to science.
\end{abstract}

\section{Introduction}

This is in continuation of the previous work on desmids collected from some selected areas of Bangladesh and published under the same title in the same journal (Islam and Akter 2004). The latter paper dealt with the genus Staurastrum Meyen, in which 30 taxa belonging to it have been described. In the present instalment further addition of 13 taxa belonging to the same genus, not included in the previous paper, have been made. Of these taxa included here, eight taxa are new records for Bangladesh and two taxa are new to science. The new taxa and new records are marked by the asterisk (*) in the text.

\section{Materials and Methods}

For details see Islam and Akter (2004).

\section{Taxonomy}

Class: Chlorophyceae; Order: Desmidiales; Family: Desmidiaceae Genus: Staurastrum Meyen

1. *Staurastrum excavatum West \& West var. spinosum Islam and Akter var. nov.

(Pl. 1, Figs. 14-15)

Cell medium-small, with distinct notch-like median constriction; broader than long; cell length without process $11.5 \mu \mathrm{m}$; mid-diam. without processes $10.3 \mu \mathrm{m}$, with processes 37-54 $\mu \mathrm{m}$; isthmus $5.2 \mu \mathrm{m}$; differs from the typical by its shorter length and greater breadth, and with one large spine at the basal angles of each semicell; additional spines are present on the cell wall and the processes are relatively longer; top view is somewhat twisted; apex with distinct depression.

Specimen studied: Collection No. $\mathrm{KG}_{2}$, Collected from a ditch near the Kaliganj Railway station, Gazipur district, on 12 September 1989. 
1. *Staurastrum excavatum West \& West var. spinosum Islam and Akter var. nov.

(Pl. 1, Figs. 14-15)

Cellulis medio-parvus, cum mediano incisura distinctus; aspectus apicalis aliquantum tortus; membrana cellulis spinosus; apicalis cum dipressio distinctus; cellulis sine processibus $11.5 \mu \mathrm{m}$ longis; medio-diam. sine processibus $10.3 \mu \mathrm{m}$, cum processibus 37-54 $\mu \mathrm{m}$; isthmus $5.2 \mu \mathrm{m}$; varieties a typo divergens a longitudo brevis; diametro latus, et unus spina ad angulis basalis et semicellulis; membrana cellulis spinosus.

Typus: Pl. 1 Figs. 14-15; Type locality: a ditch near the Kaliganj Railway station, Gazipur district. on 12 September 1989.

2. *St. indentatum West and west fa. minus Scott \& Prescott

(Pl. 1, Figs. 5-6)

(Scott \& Prescott 1961, 96, Pl. 50, Figs. 8,9)

In cell shape and ornament this form is similar to the typical form, but is much smaller and with shorter processes; cell length 34-37 $\mu \mathrm{m}$; mid-diam at base without processes $17.1 \mu \mathrm{m}$; with processes 59-62.5 $\mu \mathrm{m}$; isthmus 5.7-7.1 $\mu \mathrm{m}$; a form with two large spines at the apex of the semicell; arms more or less horizontal.

Specimens studied: Collection No. $\mathrm{KG}_{3}$, from a rice-field near the Kaliganj Railway station, district Gazipur; collected on 4 November, 1989; common in the collection.

\section{St. leptocladum var. cornutum West \& West}

(Islam and Haroon 1980, Pl. 17: 243)

Cell L. without spines $36.9 \mu \mathrm{m}$; L. with processes $38.8 \mu \mathrm{m}$; mid-diam without processes $17.1 \mu \mathrm{m}$, with processes $82.4 \mu \mathrm{m}$; isthmus $7.1 \mu \mathrm{m}$; the process are horizontally elongted; dentatum at the base of each semicell present.

Specimen studied: Collection No. $\mathrm{KG}_{2}$, from a rice-field near the Kaliganj Railway station, Gazipur district, on 12 September 1989.

\section{4. *St. leptocladum Nordst., var. smithii Grönblad}

(Pl. 1, Figs. 7-9)

(Förster 1969, Pl. 38: 1; 1974, 179, Pl. 24: 1-4)

In shape and size it fits well with this variety as shown by Förster (1969, Pl. 38: 1) from Brazil. His illustrations of the same taxon in 1974 are little different; cell length without spine $39.8 \mu \mathrm{m}$; mid diam. without processes $17.1 \mu \mathrm{m}$, and with processes 85.2 $\mu \mathrm{m}$; isthmus $5.7 \mu \mathrm{m}$ broad.

Specimen studied: Collection No. $\mathrm{KG}_{3}$, from a rice-field near Kaliganj Railway station on 4 November, 1989.

5. *St. leptocladum var. subinsigne Scott \& Grönblad

(Pl. 1, Figs. 10-11)

(Scott and Grönblad 1957, Pl. 22: 8) 


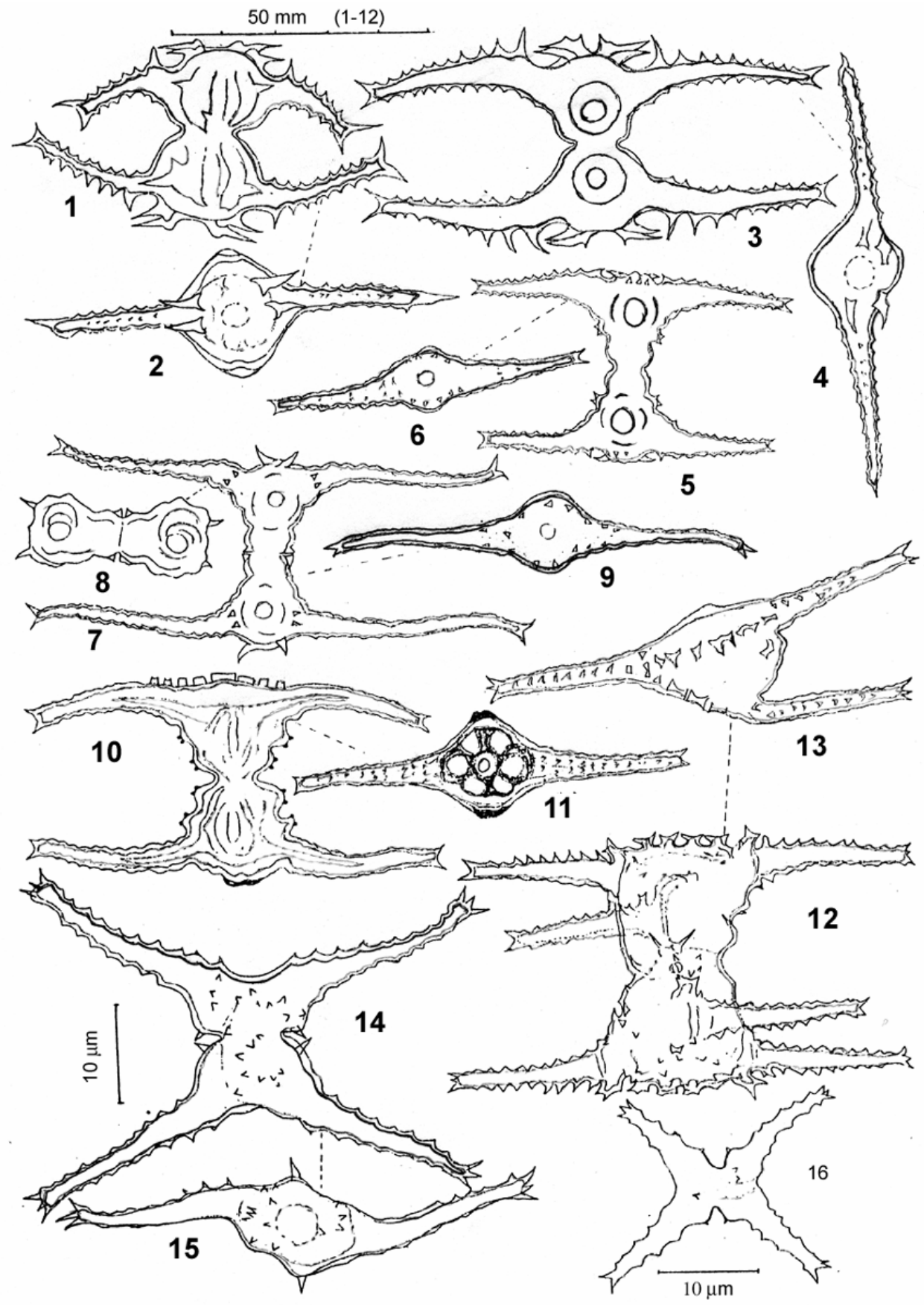

Plate 1 (Figs. 1-16)

Figs. 1-2. Staurastrum saltans var. javanicum; 3-4. St. saltans var. sumatranum; 5-6. St. indentatum fa. minus; 7-9. St. leptocladum var. smithii; 10-11. St. leptocladum var. subinsigne; 12-13. St. subjavanicum sp.nov.; 14-15. St. excavatum var. spinosum var. nov. 16. St. tetracerum. 
Cell length with spines $37 \mu \mathrm{m}$; mid-diam. at base without processes $20 \mu \mathrm{m}$, with processes $75.3 \mu \mathrm{m}$; isthmus $8.5 \mu \mathrm{m}$;

Note: Slightly smaller than the typical.

Specimen studied: Collection No. $\mathrm{KG}_{1}$, from a ditch near Kaliganj Railway station, on 14 August, 1989.

6. *St. pinnatum Turner var. hydra Krieger fa.

(Pl. 2, Figs. 19-20)

(Grönblad et al. 1968, 24, Fig. 138).

Cell small, length without spines $25.6 \mu \mathrm{m}$; mid-diam. without process $15.4 \mu \mathrm{m}$, with process $36 \mu \mathrm{m}$; isthmus $9 \mu \mathrm{m}$ broad; each semicell with 5 arms or proceses at top view; 2 additional processes at the base of each arm/process; main process/arm is not bifurcated, spines absent on cell wall; it slightly differs from the African specimens shown by Grönblad et al. (1968).

Specimen studied: Collection from a ditch near Kaliganj railway station, district Gazipur, on 14 August 1981 and also from a pond at Cox's Bazar by squeezing Utricularia sp.; common in all collections.

\section{7. *St. pinnatum Turner var. hydra Krieger fa. supernumerarium Scott \& Prescott}

(Scott and Prescott 1961, 101, Pl. 46, Fig. 7)

(Pl. 2, Figs. 17-18)

The cell is similar in shape, size and ornamentation to the variety, but with an extra small quadrifid verruca on the left side of each of the principal processes; cell with processes $24.5 \mu \mathrm{m}$ long; mid-diam. without process $14.1 \mu \mathrm{m}$; with processes $34.4 \mu \mathrm{m}$; isthmus $7.7 \mu \mathrm{m}$ broad; cell wall with small spines.

Note: Almost similar structure, but poorly drawn, was shown by Turner (1892, Pl. 13, fig. 28) as St. ornatum (Boldt) Turner (L. $38 \mu \mathrm{m}$; Br. $42 \mu \mathrm{m}$; isth. $12 \mu \mathrm{m}$; process 11 $\mu \mathrm{m})$. The above forma of Scott and Prescott (l.c.) is almost similar in size and most likely the same taxon as that of Turner (L. $30 \mu \mathrm{m}$; Br. $44 \mu \mathrm{m}$ with processes, Isthmus $12 \mu \mathrm{m}$ )

Specimen studied: Collected from a ditch near Kaliganj railway station, Gazipur district, on 12 September 1989.

8. *St. pinnatum Tumer var. simplex Turner

(Pl. 2, Figs. 21-22)

(Turner 1892, Pl. 13, fig. 29)

Cell small, broader than long; cell length with spines $30 \mu \mathrm{m}$; mid-diam. without process $20.5 \mu \mathrm{m}$, with process $47.5 \mu \mathrm{m}$; isthmus $11.5 \mu \mathrm{m}$; it is somewhat smaller than the typical.

Specimen studied: Collected from a ditch near Kaliganj Railway station, Gazipur district, on 14 August 1989; common in the collection. 


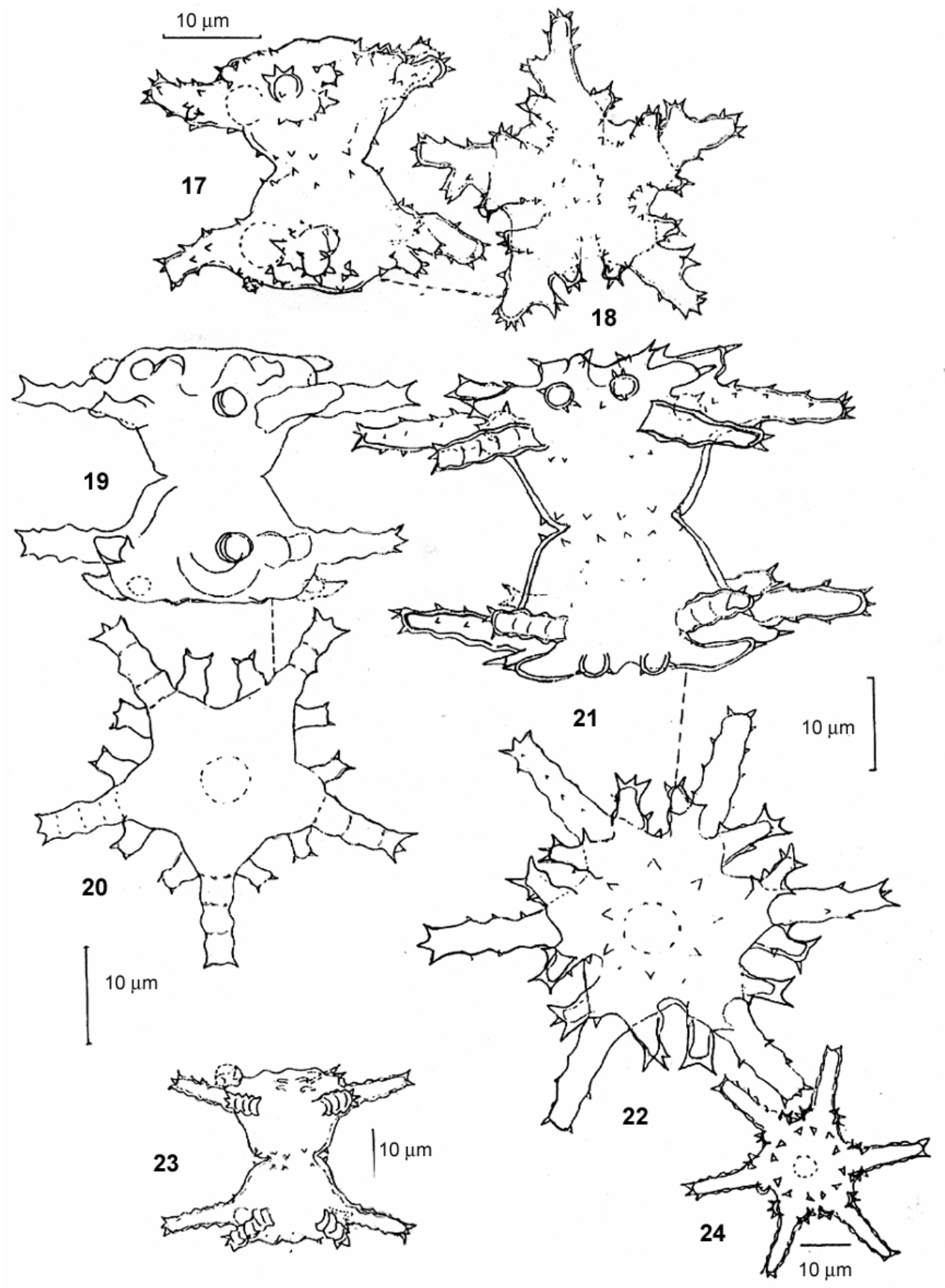

Plate 2 (Figs. 17-24)

Figs.17-18. Staurastrum pinnatum var. hydra fa. supernumerarium; 19-20. St. pinnatum var. hydra fa.; 21-22. St. pinnatum var. simplex; 23-24. St. pinnatum var. subpinnatum. 
9. St. pinnatum Turner var. subpinnatum W. \& W. fa.

(Pl. 2, Figs. 23-24)

Cell small, slightly broader than long; cell length $35.5 \mu \mathrm{m}$; mid-diam. without process $20 \mu \mathrm{m}$, with process $54 \mu \mathrm{m}$; isthmus $11.4 \mu \mathrm{m}$; a form with diverging arm, prominent spine at the base of isthmus, relatively few number of spines on the cell wall; it differs from the typical.

Specimen studied: Collected from a Khilkhet beel, Dhaka by squeezing the hydrophytes on 6 September, 1989; common in the collection.

10. *St. saltaus Joshua var. javanicum Scott and Prescott

(Pl. 1, Figs. 1-2)

(Scott and Prescott 1961, 105, Pl. 57: 8,9)

Cell length with the spines $37 \mu \mathrm{m}$; mid-diam. without processes $22.7 \mu \mathrm{m}$, with processes $62.5 \mu \mathrm{m}$; isthmus $8.5 \mu \mathrm{m}$; this is slightly smaller in length than the typical.

Specimen studied: Collection No. $\mathrm{KG}_{2}$, collected from a ditch near the Kaliganj Railway station, Gazipur district; collected on 12 September, 1989; common in the collection.

11. *St. saltans Joshua var. sumatranum Scott and Prescott.

(Pl. 1, Figs. 3-4)

(Scott and Prescott 1961, 106, Pl. 51: 3,4)

Cell length without spines $34.1 \mu \mathrm{m}$; with spines $42.6 \mu \mathrm{m}$; mid-diam. without processes $20 \mu \mathrm{m}$; with processes $91 \mu \mathrm{m}$; isthmus $8.5 \mu \mathrm{m}$; a form with narrow isthmus.

Specimen studied: Collection No. $\mathrm{KG}_{2}$, from a ditch near the Kaliganj Railway station, Gazipur distract, collected on 22 September 1989; common in the collection.

Note: Our specimen is like the typical form as shown by Scott and Prescott (1961, Pl. 51, fig. 3).

12. *Staurastrum subjavanicum Islam and Akter sp. nov.

(Pl. 1, Figs. 12-13)

Cell medium-large, broader than long, with prominent depression/incision at middle; each semicell with 3-radating arms/processes, apical 2 horizontal and the third process developed from almost the mid-region of the semicell, straight but twisted at the base; process margins serrated; apical margin with bifurcated spines, 2 bigger spines one at each apical corner and 4 small spines in between; at the apex; top view triangular with asymmetric arrangement of the central arm; cell length with spines $57 \mu \mathrm{m}$; mid-diam. without processes $25.5 \mu \mathrm{m}$; with processes $96.5 \mu \mathrm{m}$; isthmus $14.2 \mu \mathrm{m}$ broad; bifurcated spines are present at the base of each arm/process.

Holotype: Pl. 1, Figs. 12-13; Collection No. Utt 1 , collected from a shallow pond (part of an old beel) opposite Uttara Shopping Centre, near Zia International Airport, Dhaka, on 6 September 1989; rare in the collection. 
Staurastrum subjavanicum Islam and Akter sp. nov.

(Pl. 1, Figs. 12-13)

Cellulis medio-grandis, latus quam longior, medianus incisura/depressus nonprofundus; semicellulis cum triprocessus, 2-apicalis horizontalis, tertius irregularis, basalis tortus; marginem processus serratis; marginem apicalis cum medio spinis bifidus ad centralis, et unus spina in quoque angulis apicalis; cellulis $57 \mu \mathrm{m}$ longis cum spinis; medio-diam. sine processes $25.5 \mathrm{~mm}$, cum processus $96.5 \mu \mathrm{m}$; isthmus $14.2 \mu \mathrm{m}$ latus; bifid spinis in quoque basalis ad processus.

Holotypus: Pl. 1, Figs. 12-13.

13. *St. tetracerum Ralfs

(Pl. 1, Fig. 16)

(Grönblad et al. 1968, 25, Pl. 9, figs. 140, 141; Scott \& Prescott 1961, 112, Pl. 57, fig. 12)

Cell length without processes $8.9 \mu \mathrm{m}$; mid-diam. without processes $7.7 \mu \mathrm{m}$, with processes $19.2 \mu \mathrm{m}$; isthmus $3.8 \mu \mathrm{m}$; in shape and size it is similar to Sierra Leone material shown by Gönblad et al. (1968).

Specimen studied: Collected from a ditch near the Kaliganj Railway station; Gazipur district, on 14 August 1989; common in the collection no. $\mathrm{KG}_{1}$.

\section{References}

Förster, K. 1969. Amazonische Desmidiaceen. Amazonia, 2: 5-116, + Pl. 1-56.

Grönblad, R., Scott, A.M. and Croasdale, H. 1968. Desmids from Sierra Leone, Tropical West Africa. Acta Bot. Fennica, 78: 1-41.

Islam, A.K.M. Nurul and Akter, N. 2004. Desmids from some selected areas of Bangladesh. 2. Genus Staurastrum Meyen. Bangladesh J. Plant Taxon. 11(2): 15-28.

Islam, A.K.M. Nurul and Haroon, A.K.Y. 1980. Desmids of Bangladesh. Int. Rev. ges. Hydrobiol. 65(4): 551-604.

Scott, A.M. and Grönblad, R. 1957. New and interesting desmids from the southern United States. Acta Soc. Sci. Fennicae, n.s. 811(8): 1-62 + Pls. 1-37.

Scott, A.M. and Prescott, G.W. 1961. Indonesian Desmids. Hydrobiologia, 17: 1-132 + Pl.s. 1-63.

Turner, W.B. 1892. Freshwater algae of East India. Kg. Sv. Vet. Akad. Handl. 25(5): 1-187 + Pls. 1-23. 